\title{
The Demand Analysis of Life Insurance for Ethnic Regions in Gansu Province in China
}

\author{
Jianshen Zhang ${ }^{1}$ \\ ${ }^{1}$ School of Economics, Northwest University for Nationalities, Lanzhou, China \\ Correspondence: Jianshen Zhang, Associate Professor, School of Economics, Northwest University for Nationalities, \\ Lanzhou 730124, China. E-mail: jingjizjsh@163.com
}

Received: July 4, 2014

Accepted: July 15, 2014

Online Published: July 19, 2014

doi:10.5430/ijba.v5n4p108

URL: http://dx.doi.org/10.5430/ijba.v5n4p108

This work was supported by the Fundamental Research Funds for the Central Universities of Northwest University for Nationalities (Grant No.31920130096).

\begin{abstract}
This paper analyzed life insurance demand for ethnic regions in Gansu province in China, using the large and high-quality micro sample provided by China household finance survey(CHFS). From the perspective of the demography variables, culture and psychological factors and protection patterns, the authors investigate and analyze ethnic life insurance ownership ratio, the specific types of insurance as well as the insurance coverage amount in Gansu province. There are few domestic literature studies this problem from individual level, so this paper plays a beneficial role for further study on this topic.
\end{abstract}

Keywords: life insurance demand, demography, culture and psychological factors, protection patterns

\section{Introduction}

As for the fundamental problem for life insurance demand, the domestic research focus on relatively more macroscopic level, such as the economic growth, institutional change, international comparison, regional disparity and financial development. Most of the data in these studies derived from various yearbooks, but it is hard to go for an accurate analysis of individual level by using the summed or averaged data, and the sample size which can be used to be investigated is usually absent. Compared to the research in developed regions in China, there is little analysis about life insurance demand from the individual level for ethnic regions in Gansu province in China. One important reason is that there are a large number of follow-up surveys in developed regions, the surveys are in a large scale, continuing for a long time, and generate a lot of micro-data that detailed and easy to obtained, but the relevant data used by the domestic scholars for ethnic regions is relatively scarce.

Based on the large sample, high quality micro-data of China household finance survey to quantitatively describe and analyze the life insurance demand status of Chinese, unlike previous literature using only life insurance income to measure life insurance demand, the life insurance demand in this paper is measured by life insurance rate, kind of insurance and insurance amount. The paper is organized as follows: Section 2 introduces the overall situation of residents' life insurance demand in ethnic regions. Section 3 analyzes demographic variables such as gender, family status, life cycle, and the working state, whose impact on the residents' life insurance demand. Section 4 presents cultural and psychological factors such as the cultural degree, risk attitude and consumption idea, which influenced life insurance demand. The last section will conclude the paper.

\section{Sample and the Analysis of Overall Situation of Life Insurance Demand in Gansu}

\subsection{Sample Introduction}

The data used in this paper derived from China household finance survey. The survey is organized by the public welfare of academic research institutions-Chinese family financial investigation and research center, which was established jointly by the people's bank of China financial institute and Southwestern University of Finance and Economics, the survey results aim to build a basic database of Chinese family financial in microcosmic field.

CHFS made the first investigation in 2011, and the sample distributed in 25 provinces (cities, districts), 80 counties 
(area, city), and 320 village committees, involving more than 8400 households. This investigation asked the informants who are twenty years of age or older and their spouses the question about "insurance and safeguard". This paper is based on parts of the samples with regard to ethnic regions in Gansu province. Handling the original observation by cleaning, grouping, generating a virtual variable or classifying variable, calculating weight distribution, and grouping values, we analyzed ten statistical description forms in this paper.

\subsection{The Overall Situation of Commercial Insurance Demand}

Table 1 estimated the overall situation of the commercial insurance demand in ethnic regions in Gansu, and it is easy to find that popularity degree of commercial insurance products is still very low. Among them, the highest insurance rate product-life insurance is only accounted for $5.62 \%$; health product is in the second position, accounting for $3.18 \%$. Secondly, personal insurance rates are higher than property insurance (except car insurance), it is in agreement that the personal insurance has stronger life service properties, and the property insurance has stronger production service properties. Thirdly, the insurance rate of urban residents is more than twice as that of rural residents, because "other commercial insurance" includes the agricultural insurance, it makes the index gap narrower between rural residents and urban residents' insurance rate. Thus, the gap of life insurance between urban and rural areas is inevitable. Considering the popularization in the rural in Gansu is mainly small personal insurance. The insurance rate gap between rural and urban areas cannot fully reflect the real difference of urban and rural development of life insurance.

Table 1. Commercial insurance status of individual citizens

\begin{tabular}{|c|c|c|c|c|c|c|c|}
\hline & & $\begin{array}{l}\text { Life } \\
\text { Insurance }\end{array}$ & $\begin{array}{l}\text { Health } \\
\text { Insurance }\end{array}$ & $\begin{array}{l}\text { Accident } \\
\text { insurance }\end{array}$ & $\begin{array}{l}\text { Endowment } \\
\text { insurance }\end{array}$ & $\begin{array}{l}\text { Property } \\
\text { insurance } \\
\text { except car } \\
\text { insurance }\end{array}$ & $\begin{array}{c}\text { Other } \\
\text { commercial } \\
\text { insurance }\end{array}$ \\
\hline \multirow{3}{*}{$\begin{array}{l}\overrightarrow{0} \\
\stackrel{0}{D}\end{array}$} & Insured $\mathrm{N}$ & 84 & 47 & 13 & 24 & 10 & 38 \\
\hline & $\begin{array}{c}\text { Uninsured } \\
\mathrm{N}\end{array}$ & 1459 & 1051 & 1229 & 1218 & 1542 & 929 \\
\hline & $\begin{array}{l}\text { Insurance } \\
\text { Rate }\end{array}$ & $5.62 \%$ & $3.18 \%$ & $0.86 \%$ & $0.16 \%$ & $0.06 \%$ & $0.90 \%$ \\
\hline \multirow{3}{*}{ 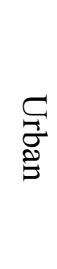 } & Insured $\mathrm{N}$ & 63 & 40 & 29 & 17 & 8 & 22 \\
\hline & $\begin{array}{c}\text { Uninsured } \\
\mathrm{N}\end{array}$ & 818 & 841 & 872 & 864 & 881 & 728 \\
\hline & $\begin{array}{l}\text { Insurance } \\
\text { Rate }\end{array}$ & $7.73 \%$ & $4.78 \%$ & $1.12 \%$ & $2.07 \%$ & $0.09 \%$ & $1.05 \%$ \\
\hline \multirow{3}{*}{ 胥 } & Insured $\mathrm{N}$ & 20 & 14 & 13 & 6 & 2 & 6 \\
\hline & $\begin{array}{l}\text { Uninsured } \\
\mathrm{N}\end{array}$ & 15 & 38 & 78 & 54 & 21 & 66 \\
\hline & $\begin{array}{c}\text { Insurance } \\
\text { Rate }\end{array}$ & $3.23 \%$ & $1.13 \%$ & $0.52 \%$ & $0.98 \%$ & $0.03 \%$ & $0.70 \%$ \\
\hline
\end{tabular}

\subsection{Proportion of Life Insurance's Main Products}

According to different types of guarantee and investment, life insurance was divided into ordinary life insurance, participating life insurance and investment-oriented life insurance. We can see from Table 2 that ordinary life insurance rate reaches $43.96 \%$, slightly higher than $42.14 \%$ of participating life insurance, both is higher than the $13.90 \%$ of investment-oriented life insurance. This is because participating life insurance laid a leading position in Gansu, although ordinary life insurance premium amount is low, the policy number is higher. From the perspective of the differences between urban and rural areas of insurance's types, there is a low proportion of participating life insurance compared with urban residents. Accordingly, there is a high proportion of ordinary life insurance and investment- oriented life insurance. 
Table 2. Residents' life insurance status

\begin{tabular}{|c|c|c|c|c|c|c|c|c|}
\hline \multirow{2}{*}{$\begin{array}{c}\text { Urban } \\
\text { and } \\
\text { rural }\end{array}$} & \multicolumn{2}{|c|}{$\begin{array}{l}\text { ordinary life } \\
\text { insurance }\end{array}$} & \multicolumn{2}{|c|}{$\begin{array}{l}\text { participating life } \\
\text { insurance }\end{array}$} & \multicolumn{2}{|c|}{$\begin{array}{l}\text { investment - oriented } \\
\text { life insurance }\end{array}$} & \multicolumn{2}{|c|}{ Total } \\
\hline & $\begin{array}{c}\text { Insurance } \\
\mathrm{N}\end{array}$ & $\%$ & $\begin{array}{c}\text { Insurance } \\
\mathrm{N}\end{array}$ & $\%$ & $\begin{array}{l}\text { Insurance } \\
\mathrm{N}\end{array}$ & $\%$ & $\begin{array}{l}\text { Insurance } \\
\qquad \mathrm{N}\end{array}$ & $\%$ \\
\hline Urban & 51 & $\begin{array}{c}44.94 \\
\%\end{array}$ & 34 & $39.88 \%$ & 51 & $15.18 \%$ & 36 & $100 \%$ \\
\hline rural & 12 & $\begin{array}{c}40.78 \\
\%\end{array}$ & 15 & $49.51 \%$ & 10 & $9.71 \%$ & 13 & $100 \%$ \\
\hline Total & 73 & $\begin{array}{c}43.96 \\
\%\end{array}$ & 49 & $42.14 \%$ & 61 & $13.90 \%$ & 49 & $100 \%$ \\
\hline
\end{tabular}

\section{Demographic Factors and Life Insurance Demand}

\subsection{Gender, Family Status with Life Insurance Demand}

Table 3 shows the life insurance demand classified by the gender and family status. We can find that the insurance rate of male is higher than the female. In general, the women's risk awareness is stronger, and has more thick family values, the female's two week prevalence rate and prevalence rate of chronic disease is higher than that of male, and the average lifetime is longer than that of male.. Secondly, head of a household's insurance rate is higher than his or her spouse; it is easy to understand the head of the household generally is a major contributor to their family income, bear the more family responsibility.

There exists difference in the type of insurance demand between the different gender and family status. Ordinary life insurance proportion reached $51.42 \%$ and $40.11 \%$ respectively insured by male, the head of the household life insurance, significantly higher than that of female. The host family in ordinary life insurance coverage for an average of 13419 Yuan and 11559Yuan, it is significantly higher than that of women, the head of the household (6232 Yuan and 4453 Yuan). In most families, male is the head of the household, who has a shorter average lifetime, heavier familial responsibility and a higher death rate, which make them choose the ordinary life insurance that more affordable.

Table 3. Gender, family status with life insurance demand

\begin{tabular}{|c|c|c|c|c|c|}
\hline \multirow{2}{*}{$\begin{array}{l}\text { Insurance } \\
\text { type }\end{array}$} & \multirow{2}{*}{ Indicators } & \multicolumn{2}{|c|}{ Gender } & \multicolumn{2}{|c|}{ Family status } \\
\hline & & male & female & $\begin{array}{l}\text { head of a } \\
\text { household }\end{array}$ & spouse \\
\hline \multirow{4}{*}{ Overall } & Insured $\mathrm{N}$ & 82 & 49 & 476 & 112 \\
\hline & Uninsured $\mathrm{N}$ & 4009 & 4094 & 6019 & 1642 \\
\hline & total & 4291 & 4443 & 6495 & 1754 \\
\hline & Insurance Rate & $6.57 \%$ & $7.86 \%$ & $7.33 \%$ & $6.39 \%$ \\
\hline \multirow{2}{*}{$\begin{array}{l}\text { Ordinary life } \\
\text { insurance }\end{array}$} & $\%$ & $51.42 \%$ & $40.11 \%$ & $49.16 \%$ & $25.00 \%$ \\
\hline & $\begin{array}{c}\text { average insured } \\
\text { value }\end{array}$ & 13419 & 6232 & 11559 & 4453 \\
\hline \multirow{2}{*}{$\begin{array}{c}\text { Participating } \\
\text { life } \\
\text { insurance }\end{array}$} & $\%$ & $31.91 \%$ & $43.55 \%$ & $36.76 \%$ & $53.57 \%$ \\
\hline & $\begin{array}{c}\text { average insured } \\
\text { value }\end{array}$ & 112499 & 118562 & 136087 & 77061 \\
\hline \multirow{2}{*}{$\begin{array}{l}\text { Investment - } \\
\text { oriented life } \\
\text { insurance }\end{array}$} & $\%$ & $16.67 \%$ & $16.33 \%$ & $14.08 \%$ & $21.43 \%$ \\
\hline & $\begin{array}{c}\text { average insured } \\
\text { value }\end{array}$ & 126422 & 123623 & 130399 & 125833 \\
\hline
\end{tabular}




\subsection{Life Cycle and the Life Insurance Demand}

There is a discrepancy of bear duty, income and expenditure in various ages indicating a discrepancy of insurance demand. It can be seen from Table 4 that middle-aged group has highest insurance rate, the group of age 30-39 and 40-49 have a insurance rate of $9.18 \%$ and $10.00 \%$, while there is a low insurance rate among the age of 20 29, $50 \sim 59$, and above 60 , so there is an inverted U-shaped relationship between the age with the insurance rate. Income of the people between the age of 20 30 is low, consumer spending is high, they would pay more attention to accumulate wealth, thus, their saving rate may be higher, other assets held on a smaller scale. The people above the age of 50 steps into the period that is stable and retirement, Family economic conditions achieve the top state, their children are completely independent, and the debt burden reduce gradually; self-preservation ability enhanced, in addition, human capital uncertainty caused by the lack of life expectancy reduced, so there is a few life insurance demand. Secondly, middle-aged group bear the hardest family burden, they have to take care of their children and parents, the impact of life's uncertainty is biggest, middle-aged group has a stronger investment consciousness than the elder. Payment ability is the strongest period of their life, thus, the middle-age group prefers ordinary life insurance, which is a pure safeguard model, and they prefer investment-oriented life insurance.

Table 4. Life cycle and the life insurance demand

\begin{tabular}{|c|c|c|c|c|c|c|}
\hline \multirow{2}{*}{$\begin{array}{l}\text { Insurance } \\
\text { type }\end{array}$} & \multirow{2}{*}{ Indicators } & \multicolumn{5}{|c|}{ Age group } \\
\hline & & $20-29$ & $30-39$ & $40-49$ & $50-59$ & Above 60 \\
\hline \multirow{4}{*}{ Overall } & Insured N & 63 & 186 & 232 & 101 & 37 \\
\hline & $\begin{array}{l}\text { Uninsured } \\
\qquad \mathrm{N}\end{array}$ & 912 & 1841 & 2088 & 1568 & 1653 \\
\hline & total & 975 & 2027 & 2320 & 1669 & 1690 \\
\hline & $\begin{array}{l}\text { Insurance } \\
\text { Rate }\end{array}$ & $6.46 \%$ & $9.18 \%$ & $10.00 \%$ & $6.05 \%$ & $2.19 \%$ \\
\hline \multirow[b]{2}{*}{$\begin{array}{l}\text { Ordinary life } \\
\text { insurance }\end{array}$} & $\%$ & $33.33 \%$ & $44.09 \%$ & $45.26 \%$ & $58.42 \%$ & $48.65 \%$ \\
\hline & $\begin{array}{c}\text { average } \\
\text { insured } \\
\text { value }\end{array}$ & 202144 & 12688 & 15175 & 23813 & 12521 \\
\hline & $\%$ & $50.79 \%$ & $39.25 \%$ & $37.07 \%$ & $28.71 \%$ & $48.65 \%$ \\
\hline $\begin{array}{l}\text { Participating } \\
\text { life insurance }\end{array}$ & $\begin{array}{c}\text { average } \\
\text { insured } \\
\text { value }\end{array}$ & 17583 & 202831 & 17558 & 18185 & 20227 \\
\hline \multirow{2}{*}{$\begin{array}{l}\text { Investment - } \\
\text { oriented life } \\
\text { insurance }\end{array}$} & $\%$ & $14.29 \%$ & $16.67 \%$ & $17.67 \%$ & $12.87 \%$ & $2.70 \%$ \\
\hline & $\begin{array}{c}\text { average } \\
\text { insured } \\
\text { value }\end{array}$ & 17400 & 16769 & 21525 & 14833 & 2000 \\
\hline
\end{tabular}

\subsection{Working Condition and the Insurance Demand}

The life insurance demand condition classified by whether to work and the working character can be seen in Table 5 . Firstly, the life insurance rate is $8.16 \%$ among the employed people, higher than $5.02 \%$ of the unemployed people. Because the employed has more incomes. Ordinary life insurance counts $46.97 \%$ among the insured life insurance of unemployed people, and the participating life insurance counts $42.93 \%$, higher than $40.79 \%$ and $40.79 \%$ of the employed people. The average ordinary life insurance coverage is 122258 Yuan, the average participating life insurance coverage is 118478 Yuan, is also higher than 74560 Yuan and 116168 Yuan of the employed people. This is because work provides the income and also provides some security and welfare; unemployed people need the safeguard ordinary life insurance and deposit participating life insurance. As for the investment of life insurance, the insurance proportion among employed people reached $18.41 \%$, and the average coverage reached 128,182 Yuan, higher than $10.10 \%$ and 126,183 Yuan of unemployed people, so it is visible that the pursuit of income from investment is increased after being employed. 
Table 5. Working condition and life insurance demand

\begin{tabular}{|c|c|c|c|c|c|c|}
\hline \multirow[b]{2}{*}{$\begin{array}{l}\text { Insurance } \\
\text { type }\end{array}$} & \multirow[b]{2}{*}{ Indicators } & \multicolumn{2}{|c|}{ employed } & \multicolumn{3}{|c|}{ Works nature (except agriculture) } \\
\hline & & Yes & No & $\begin{array}{l}\text { Employed } \\
\text { (contain the } \\
\text { restart) }\end{array}$ & $\begin{array}{l}\text { individual } \\
\text { worker }\end{array}$ & freelancer \\
\hline \multirow{4}{*}{ Total } & Insured $\mathrm{N}$ & 429 & 198 & 299 & 85 & 24 \\
\hline & Uninsured $\mathrm{N}$ & 4507 & 3592 & 3083 & 815 & 208 \\
\hline & total & 4936 & 3790 & 3382 & 900 & 232 \\
\hline & $\begin{array}{c}\text { Insurance } \\
\text { Rate }\end{array}$ & $8.16 \%$ & $5.02 \%$ & $8.84 \%$ & $9.44 \%$ & $10.34 \%$ \\
\hline \multirow[b]{2}{*}{$\begin{array}{c}\text { Ordinary life } \\
\text { insurance }\end{array}$} & $\%$ & $40.79 \%$ & $46.97 \%$ & $35.79 \%$ & $60.00 \%$ & $58.33 \%$ \\
\hline & $\begin{array}{c}\text { average } \\
\text { insured } \\
\text { value }\end{array}$ & 14560 & 12225 & 10211 & 11022 & 21400 \\
\hline \multirow{2}{*}{$\begin{array}{c}\text { Participating } \\
\text { life } \\
\text { insurance }\end{array}$} & $\%$ & $40.79 \%$ & $42.93 \%$ & $44.48 \%$ & $27.06 \%$ & $33.33 \%$ \\
\hline & $\begin{array}{l}\text { average } \\
\text { insured } \\
\text { value }\end{array}$ & 11616 & 11847 & 4977 & 13106 & 3872 \\
\hline \multirow[b]{2}{*}{$\begin{array}{l}\text { Investment - } \\
\text { oriented life } \\
\text { insurance }\end{array}$} & $\%$ & $18.41 \%$ & $10.10 \%$ & $19.73 \%$ & $12.94 \%$ & $8.33 \%$ \\
\hline & $\begin{array}{c}\text { average } \\
\text { insured } \\
\text { value }\end{array}$ & 12182 & 12183 & 12533 & 15000 & 20000 \\
\hline
\end{tabular}

As for insurance rate, the rate of individual worker and freelancer is higher than employee. Income fluctuation of individual worker and freelancer is higher than that of employee, the lack of relatively steady work inspired the people's risk perception, and promote the life insurance demand. For different life insurance products, ordinary life insurance proportion of individual worker and freelancer reached $60.00 \%$ and $58.33 \%$, is higher than $35.79 \%$ of the employee; the average insurance amount of ordinary life insurance are 13106 Yuan and 13872 Yuan, higher than 4977 Yuan of employee. The participating life insurance and investment - oriented life insurance proportion of employees is higher than that of individual worker and freelancer, the employee pay more attention to the saving and investment functions of life insurance. Finally, freelancer has the higher average coverage among the three kinds of life insurance than employees and individual worker. This is primarily attributed to the higher levels of income of freelancer

\section{Cultural Psychological Factors and the Life Insurance Demand}

\subsection{Degree of Education and Life Insurance Demand}

There are significant differences among people with different cultural levels of the life insurance demand. It can display in Table 6. The higher the level of education, the higher rate of life insurance, the average insured amount of groups with undergraduate and graduate degree is higher than other groups. Cultural degree enhances the recognition degree of insurance products, rather than the alleged "intellectual dislike insure, people don't understand the insurance is more eager to buy insurance". Secondly, there exist structural differences in insurance types among people's life insurance demand with different artistic degree. The proportion of ordinary life insurance among people with undergraduate and graduate degree is less than that among other groups; but their proportion of investment oriented life insurance is higher than others. Investment-oriented life insurance needs certain financial knowledge and the barriers to entry, hampered the some people with lower cultural degree to some extent. 
Table 6. Degree of education and life insurance demand

\begin{tabular}{|c|c|c|c|c|c|c|c|}
\hline \multirow[b]{2}{*}{$\begin{array}{c}\text { Insurance } \\
\text { type }\end{array}$} & \multirow[b]{2}{*}{ Indicators } & \multicolumn{6}{|c|}{ Degree of education } \\
\hline & & $\begin{array}{l}\text { illiter } \\
\text { acy }\end{array}$ & $\begin{array}{c}\text { Primary } \\
\text { school }\end{array}$ & $\begin{array}{l}\text { Junior } \\
\text { high } \\
\text { school }\end{array}$ & $\begin{array}{l}\text { Senior high school } \\
\text { (including Technical } \\
\text { secondary school, } \\
\text { vocational schools) }\end{array}$ & $\begin{array}{l}\text { Under } \\
\text { graduate }\end{array}$ & Graduate \\
\hline \multirow{4}{*}{ Overall } & Insured $\mathrm{N}$ & 3 & 46 & 157 & 175 & 220 & 18 \\
\hline & $\begin{array}{l}\text { Uninsured } \\
\mathrm{N}\end{array}$ & 331 & 1137 & 2606 & 2072 & 1750 & 134 \\
\hline & total & 334 & 1183 & 2763 & 1247 & 1970 & 152 \\
\hline & $\begin{array}{c}\text { Insurance } \\
\text { Rate }\end{array}$ & $\begin{array}{c}0.90 \\
\%\end{array}$ & $3.89 \%$ & $5.68 \%$ & $7.79 \%$ & $11.17 \%$ & $11.84 \%$ \\
\hline \multirow[b]{2}{*}{$\begin{array}{l}\text { Ordinary life } \\
\text { insurance }\end{array}$} & $\%$ & $\begin{array}{c}0.00 \\
\%\end{array}$ & $45.65 \%$ & $54.14 \%$ & $54.29 \%$ & $31.36 \%$ & $38.89 \%$ \\
\hline & $\begin{array}{c}\text { average } \\
\text { insured } \\
\text { value }\end{array}$ & -- & 6522 & 8856 & 5082 & 11980 & 126000 \\
\hline \multirow{2}{*}{$\begin{array}{c}\text { Participating } \\
\text { life } \\
\text { insurance }\end{array}$} & $\%$ & $\begin{array}{c}100.0 \\
0 \%\end{array}$ & $50.00 \%$ & $36.31 \%$ & $31.43 \%$ & $48.18 \%$ & $27.78 \%$ \\
\hline & $\begin{array}{c}\text { average } \\
\text { insured } \\
\text { value }\end{array}$ & 5000 & 6407 & 6551 & 4449 & 18382 & 208333 \\
\hline \multirow{2}{*}{$\begin{array}{l}\text { Investment - } \\
\text { oriented life } \\
\text { insurance }\end{array}$} & $\%$ & $\begin{array}{c}0.00 \\
\%\end{array}$ & $4.35 \%$ & $9.55 \%$ & $14.29 \%$ & $20.45 \%$ & $33.33 \%$ \\
\hline & $\begin{array}{c}\text { average } \\
\text { insured } \\
\text { value }\end{array}$ & -- & 5000 & 11500 & 10213 & 13341 & 285000 \\
\hline
\end{tabular}

\subsection{Risk Attitude and Life Insurance Demand}

Table 7 show the life insurance demand among five kinds of people with different risk attitude. Surprisingly, people who hate to risk more, the insurance rate is lower instead, people chose "low risk, low return" and "do not want to take any risk" has an insurance rate only at $7.14 \%$ and $4.02 \%$. There are three reasonable understandings: Firstly. Risk attitude did not influence the residents to decide making insurance; it means people's lack of risk awareness and inadequate recognition of insurance products. Secondly, because the average coverage of the people "does not want to take any risk" is far less than other people, lower ability to pay should be one reason that leads to the low insurance rate. Thirdly, because insurance rate differences caused people have different safeguard levels, which lead the low insurance rates people choose low risk behavior, and the high insurance rates people choose high risk behavior.

Table 7. Risk attitude and life insurance demand

\begin{tabular}{ccccccc}
\hline & & \multicolumn{5}{c}{ Risk attitude } \\
\cline { 3 - 7 } $\begin{array}{c}\text { Insurance } \\
\text { type }\end{array}$ & Indicators & $\begin{array}{c}\text { High } \\
\text { risk, high } \\
\text { return }\end{array}$ & $\begin{array}{c}\text { Slightly high } \\
\text { risk, Slightly } \\
\text { high return }\end{array}$ & Middle & $\begin{array}{c}\text { Slightly lower } \\
\text { risk, Slightly } \\
\text { lower return }\end{array}$ & $\begin{array}{c}\text { Don't } \\
\text { want to } \\
\text { take any } \\
\text { risks }\end{array}$ \\
\hline \multirow{2}{*}{ Overall } & $\begin{array}{c}\text { Insured N } \\
\text { Uninsured } \\
\mathrm{N}\end{array}$ & 52 & 83 & 247 & 110 & 137 \\
total & 506 & 662 & 2152 & 1431 & 3269 \\
\hline
\end{tabular}




\begin{tabular}{ccccccc}
\hline & $\begin{array}{c}\text { Insurance } \\
\text { Rate } \\
\%\end{array}$ & $9.32 \%$ & $11.14 \%$ & $10.30 \%$ & $7.14 \%$ & $4.02 \%$ \\
$\begin{array}{c}\text { Ordinary life } \\
\text { insurance }\end{array}$ & $\begin{array}{c}\text { average } \\
\text { insured } \\
\text { value } \\
\%\end{array}$ & $63.62 \%$ & $33.73 \%$ & $42.91 \%$ & $38.18 \%$ & $35.26 \%$ \\
$\begin{array}{c}\text { Participating } \\
\text { average } \\
\text { insured } \\
\text { value } \\
\text { insurance }\end{array}$ & $76.54 \%$ & $47.40 \%$ & $42.10 \%$ & $50.12 \%$ & $41.61 \%$ \\
$\begin{array}{c}\text { Investment - } \\
\text { oriented life } \\
\text { insurance }\end{array}$ & $\begin{array}{c}\text { average } \\
\text { insured } \\
\text { value }\end{array}$ & 15421 & 10846 & 22771 & 11176 & 17851 \\
\hline
\end{tabular}

Meanwhile, it can be seen from Table 7 that the risk attitude influence people choose insurance types. Firstly, people with "do not want to take any risk" have the strongest safeguard demand. Ordinary life insurance occupies the highest proportion of $35.26 \%$. Secondly, the three kings of people with risk attitude between two parties has the proportion of participating life insurance reached $47.40 \%, 42.10 \%$ and $50.12 \%$, which are higher than the people with risk attitude at both ends of the crowd, This corresponds to the characteristics of a relatively balanced between safeguard and investment of participating life insurance. Thirdly, people choose "high risk, high return" hold the proportion of investment-oriented life insurance reached $27.65 \%$, it is far higher than other people, so the investment -oriented life insurance is more suitable for the people want high floating profit and has strong risk tolerance.

\subsection{Consumption Concept and Life Insurance Demand}

The question of "weather cost more if asset values are rising" inspects the consumption tendency. It can be seen from Table 8 that the group with the tendency of cost more has a higher insurance rate. People with a more moderate consumption concept may regard life insurance as a sheer consumer good, but they do not realize the safeguard and savings function of life insurance. Secondly, investment - oriented life insurance occupies the higher proportion among people with the tendency of cost more, but the proportion of ordinary life insurance is lower. People with a tendency to cost more have stronger self-preservation ability generally, so they can invest more. Thirdly, a person with a tendency to cost more has higher average insured value of participating life insurance and investment-oriented life insurance.

Table 8. Consumption concept and life insurance demand

\begin{tabular}{|c|c|c|c|c|c|c|}
\hline \multirow{2}{*}{$\begin{array}{l}\text { Insurance } \\
\text { type }\end{array}$} & \multirow[b]{2}{*}{ Indicators } & \multicolumn{5}{|c|}{ weather cost more if asset values is rising } \\
\hline & & Very willing & Willing to & General & Reluctant & $\begin{array}{c}\text { Very } \\
\text { reluctant }\end{array}$ \\
\hline \multirow{4}{*}{ Overall } & $\begin{array}{l}\text { Insured } \\
\text { Number }\end{array}$ & 85 & 330 & 136 & 73 & 7 \\
\hline & $\begin{array}{l}\text { Uninsured } \\
\text { Number }\end{array}$ & 268 & 1219 & 999 & 773 & 116 \\
\hline & total & 253 & 549 & 213 & 186 & 123 \\
\hline & $\begin{array}{c}\text { Insurance } \\
\text { Rate }\end{array}$ & $8.92 \%$ & $9.30 \%$ & $6.37 \%$ & $3.95 \%$ & $3.14 \%$ \\
\hline \multirow{2}{*}{$\begin{array}{l}\text { Ordinary life } \\
\text { insurance }\end{array}$} & $\%$ & $45.88 \%$ & $48.48 \%$ & $39.71 \%$ & $34.25 \%$ & $42.86 \%$ \\
\hline & $\begin{array}{c}\text { average } \\
\text { insured } \\
\text { value }\end{array}$ & 8252 & 12060 & 3305 & 10306 & 1820 \\
\hline Participating & $\%$ & $23.53 \%$ & $33.03 \%$ & $50.00 \%$ & $57.53 \%$ & $42.86 \%$ \\
\hline
\end{tabular}




\begin{tabular}{ccccccc}
\hline life & $\begin{array}{c}\text { average } \\
\text { insurance } \\
\text { insured } \\
\text { value } \\
\%\end{array}$ & 12071 & 11067 & 5332 & 6560 & 1431 \\
$\begin{array}{c}\text { Investment }- \\
\text { oriented life } \\
\text { insurance }\end{array}$ & $\begin{array}{c}\text { average } \\
\text { insured } \\
\text { value }\end{array}$ & $10.82 \%$ & $18.48 \%$ & $10.29 \%$ & $8.22 \%$ & $0.00 \%$ \\
\hline
\end{tabular}

\section{Conclusion and Implications}

This paper uses individual sample provided by CHFS analyze the life insurance demand status of residents in ethnic regions in Gansu province in China, the main findings are: insurance popularity of family is still very low, the gap between urban and rural is vast; demographic variables, cultural and psychological factors, and other support methods both affected the degree of residents' life insurance and specific insurance type. The author hopes the description and interpretation in this paper can provide some enlightenment and reference for future researcher and policy maker in ethnic regions.

\section{References}

Ando, A., \& Modigliani, F. (1963). The Life-Cycle Hypothesis of Saving: Aggregate Implications and Tests. American Economic Review, 53(1), 55-84.

Beck, T., \& Webb, I. (2003). Economic, Demographic, and Institutional Determinants of Life Insurance Consumption across Countries. The World Bank Economic Review, 17(1), 51-88. http://dx.doi.org/10.1093/wber/lhg011

Beenstock, M., Dickinson, G., \& Khajuria, S. (1986). The Determination of Life Premiums: An International Cross-section Analysis. Insurance: Mathematics and Economics, 5(4), 261-270. http://dx.doi.org/10.1016/0167-6687(86)90020-X

Browne, M. J., \& Kim, K. (1993). An International Analysis of Life Insurance Demand. Journal of Risk and Insurance, 60(4), 676-634. http://dx.doi.org/10.2307/253382

Gandolfi, A. S., \& Miners, L. (1996). Gender-Based Differences in Life Insurance Ownership. The Journal of Risk and Insurance, 63(4), 63-693. http://dx.doi.org/10.2307/253478

Hammond, J. D., Houston, D. B., \& Melander, E. R. (1967). Household Life Insurance Premium Expenditures: An Empirical Approach. Journal of Risk and Insurance, 34(3), 397-408. http://dx.doi.org/10.2307/250854

Lewis, E. D. (1989). Dependents and the Demand for Life Insurance. American Economic Review, 79(3), $452-467$.

Li, D., Moshirian, F., Nguyen P., \& Wee, T. (2007). The demand for life insurance in OECD countries. Journal of Risk \& Insurance, 74(3), 637-652. http://dx.doi.org/10.1111/j.1539-6975.2007.00228.x

Mantis, G., \& Farmer, R. (1968). Demand for life insurance. Journal of Risk and Insurance, 35(2), 247-256. http://dx.doi.org/10.2307/250834

Outreville, J. F. (1996). Life Insurance Markets in Developing Countries. Journal of Risk and Insurance, 63(2), 263-278. http://dx.doi.org/10.2307/253745

Showers, W. E., \& Shotick, J. A. (1994). The effects of household characteristics on demand for insurance: A Tobit analysis. Journal of Risk and Insurance, 61(3), 492-502. http://dx.doi.org/10.2307/253572

Truett, D. B., \& Truett, L. J. (1990). The Demand for Life Insurance in Mexico and the United States: A Comparative Study. Journal of Risk and Insurance, 57(2), 321-328. http://dx.doi.org/10.2307/253306

Ward, D., \& Zurbruegg, R. (2002). Law, Politics and Life Insurance Consumption in Asia. Geneva Papers on Risk and Insurance, 27(3), 395-412. http://dx.doi.org/10.1111/1468-0440.00181 